\title{
The relation of fetal growth to plasma glucose in young men
}

\author{
S. Robinson ${ }^{1}$, R.J. Walton ${ }^{2}$, P.M. Clark ${ }^{3}$, D.J.P. Barker ${ }^{1}$, C.N.Hales ${ }^{3}$ and C. Osmond ${ }^{1}$ \\ ${ }^{1}$ MRC Environmental Epidemiology Unit, Southampton General Hospital, ${ }^{2}$ Shirley Health Centre, Southampton and \\ ${ }^{3}$ Department of Clinical Biochemistry, Addenbrookes Hospital, Cambridge, UK
}

\begin{abstract}
Summary. In a study of men aged 59 to 70 years plasma glucose levels $30 \mathrm{~min}$ and $2 \mathrm{~h}$ after a $75 \mathrm{-g}$ glucose load were inversely related to birthweight. To determine whether there are similar relations at a younger age the 30 -min plasma glucose levels of 40 men aged 21 years, who were born in one hospital in the United Kingdom, were measured. Lower
\end{abstract}

birthweight was associated with higher 30-min plasma glucose levels. This trend was independent of gestational age, and current body mass, height and social class.

Key words: Plasma glucose, birthweight, intrauterine growth.
Reduced growth during fetal life and infancy is associated with increased death rates from cardiovascular disease in adult life [1, 2]. Among 5654 men in Hertfordshire, UK, followed-up from birth it was found that those who had the lowest weights at birth and at age one year had, as adults, higher death rates from ischaemic heart disease [1]. The rates among men who weighed $8.2 \mathrm{~kg}$ (18 pounds) or less at one year of age were three times higher than those who weighed more than $11.8 \mathrm{~kg}$ (26 pounds). These long-term associations of retarded early growth are thought to result from programming, by which adverse influences at critical periods of fetal or infant development irrecoverably constrain the growth of organs and tissues and permanently change their metabolism and/or structure. The phenomenon of 'programming' has been demonstrated in brain development and in a range of structures and functions in experimental animals [3].

There is evidence that Type 2 (non-insulin-dependent) diabetes mellitus, which is associated with ischaemic heart disease, is programmed in fetal life and infancy. A study of 370 Hertfordshire men aged 59 to 70 years showed that plasma glucose levels $30 \mathrm{~min}$ and $2 \mathrm{~h}$ after a $75 \mathrm{-g}$ oral glucose load were inversely related to birthweight and to weight at the age of one year [4]. This was a strong relationship and was independent of body mass index. The percentage of men with impaired glucose tolerance (2-h glucose 7.8-11.0 mmol/1) or newly-diagnosed diabetes (2-h glucose $\geq 11.1 \mathrm{mmol} / \mathrm{l}$ ) fell progressively from 40 to 14 as birthweight increased from $2.5 \mathrm{~kg}$ (5.5 pounds) to more than $4.3 \mathrm{~kg}$ ( 9.5 pounds).
It could be argued that lower birth and infant weight merely indicate an adverse early environment, and that people born into an adverse environment tend to remain in one. Therefore, associations with early growth could reflect influences acting later in life, though the associations are strong and graded which makes this unlikely. It is also possible that the associations depend on influences which affected fetal growth in the past but are no longer present in the environment today. We have therefore studied glucose tolerance in a group of young men aged 18 to 25 years.

\section{Subjects and methods}

Sixty-seven men aged 18-25 years who were on the general practice list of one of the authors (R.J.W.) and were born in Southampton Hospital Maternity Unit, were asked to take part in the study, 42 $(64 \%)$ agreed to do so. Obstetric data were obtained from their mothers' antenatal and delivery records. These data included birthweight, placental weight and head circumference. Gestational age derived from the date of the last menstrual period was recorded for all except two of the men. The final sample size represented all men in the age range who were on the practice list and who had complete obstetric records.

All the men were seen at the health centre having fasted overnight. Using a structured questionnaire they were asked about their medical history, smoking habits and alcohol intake. Their waist circumferences and hip girths were measured. Height was measured using a portable stadiometer and weight with a portable Seca scale. Blood pressure was measured with an automated recorder (Dinamap, Critikon, Tampa, Fl., USA) with the subject sitting down. Readings were taken on the left arm using the cuff size recommended for the arm circumference. Two readings were taken and the average used in the analysis. 
The men were given a standard 75-g oral glucose load. A blood sample was taken after $30 \mathrm{~min}$. Measurements made on the blood sample were glucose, insulin and proinsulin. Plasma glucose was measured by a hexokinase method. Plasma insulin and proinsulin were determined using two-site immunoradiometric assays [5]. The insulin assay was standardized against the first IRP coded 66/304 and the proinsulin assay against a standard obtained from Lilly Research Laboratories (Indianapolis, Ind., USA).

Ethical permission for the study was given by the Southampton Ethics Committee.

\section{Statistical analysis}

Statistical analysis was by multiple linear regression and tabulation of means. Because the plasma measurements of insulin and proinsulin have skewed distributions we transformed them in the analysis by using logarithms. Social class was defined according to father's occupation [6]. The social class of three fathers was unknown.

\section{Results}

The age of the men ranged from 18 to 25 years with a mean of 21.1 (SD 2.0) years. Their mean birthweight was 3413 (SD 373) g. The mean age of the 25 men who declined to take part in the study was 21.2 (SD 2.0) years. Their mean birthweight was 3282 (SD 372)g. The mean plasma glucose at $30 \mathrm{~min}$ of the $42 \mathrm{men}$ was $8.2 \mathrm{mmol} / \mathrm{l}$. Two men had values of 11.2 and $11.5 \mathrm{mmol} / \mathrm{l}$, which exceed the level defining diabetes [7]. The men who are likely to have Type 1 (insulin-dependent), rather than Type 2 diabetes, were excluded from the analyses. Their birthweights were $3402 \mathrm{~g}$ and $3983 \mathrm{~g}$.

In Table 1 the subjects are divided into three groups according to birthweight. Thirty-min plasma glucose levels fell from the lowest to the highest birthweight group. The inverse association between birthweight and plasma glucose was such that an increase of $1 \mathrm{~kg}$ in birthweight corresponded to a decrease of $1.5 \mathrm{mmol} / \mathrm{l}$ in 30 -min glucose (95\% confidence interval (C. I.) 0.4 to $2.6, p=0.01$ ). The trend was independent of gestational age. Thirty-min plasma glucose levels were not related to head circumference or placental weight, or to current body mass index (weight/height ${ }^{2}$ ), waist to hip ratio, height, alcohol intake or smoking.

Neither plasma insulin nor proinsulin levels were related to birthweight, head circumference or placental weight. Both measurements were related to 30 -min plasma glucose. An increase of $1 \mathrm{mmol} / 1$ of 30 -min glucose was

Table 1. Mean plasma glucose, insulin and proinsulin, body mass index and systolic blood pressure according to birthweight

\begin{tabular}{|c|c|c|c|c|c|c|}
\hline $\begin{array}{l}\text { Birthweight } \\
\text { (g) }\end{array}$ & $n$ & $\begin{array}{l}\text { Plasma } \\
\text { glucose } \\
(\mathrm{mmol} / \mathrm{l})\end{array}$ & $\begin{array}{l}\text { Plasma } \\
\text { insulin } \\
(\mathrm{pmol} / \mathrm{l})\end{array}$ & $\begin{array}{l}\text { Plasma } \\
\text { pro- } \\
\text { insulin } \\
\text { (pmol/) }\end{array}$ & $\begin{array}{l}\text { Body } \\
\text { mass } \\
\text { index } \\
\left(\mathrm{kg} / \mathrm{m}^{2}\right)\end{array}$ & $\begin{array}{l}\text { Systolic } \\
\text { blood } \\
\text { pressure } \\
\text { (mm Hg) }\end{array}$ \\
\hline up to 3204 & 14 & 8.8 & 244 & 4.3 & 22.5 & 145 \\
\hline up to 3572 & 13 & 8.2 & 314 & 5.3 & 24.6 & 149 \\
\hline $\begin{array}{l}\text { greater than } \\
3572\end{array}$ & 13 & 7.3 & 241 & 4.7 & 23.3 & 144 \\
\hline $\begin{array}{l}\text { ALL } \\
\text { (SD) }\end{array}$ & 40 & $\begin{array}{c}8.1 \\
(1.4)\end{array}$ & $\begin{array}{l}264 \\
(1.7)\end{array}$ & $\begin{array}{c}4.7 \\
(1.8)\end{array}$ & $\begin{array}{l}23.4 \\
(2.6)\end{array}$ & $\begin{array}{l}146 \\
(14)\end{array}$ \\
\hline
\end{tabular}

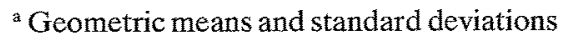

associated with an increase of 0.19 (95\% C.I. 0.10 to 0.29 , $p=0.0004)$ in $\log 30-\mathrm{min}$ insulin and an increase of 0.17 (95\% C. I. 0.05 to $0.30, p=0.01$ ) in $\log$ proinsulin. They were also weakly related to body mass index. The corresponding figures resulting from a $1 \mathrm{~kg} / \mathrm{m}^{2}$ increase in body mass index were an increase of $0.06(95 \%$ C.I. 0.00 to 0.12 , $p=0.05)$ in $\log 30-\mathrm{min}$ insulin and an increase of 0.06 $(-0.01$ to $0.13, p=0.09)$ in $\log$ proinsulin. In a multiple regression with plasma glucose and body mass index both plasma insulin and proinsulin levels rose with birthweight. An increase of $1 \mathrm{~kg}$ in birthweight corresponded to an increase of $0.36(95 \%$ C.I. 0.00 to $0.72, p=0.05)$ in $\log$ $30-\mathrm{min}$ insulin and an increase of $0.46(95 \%$ C.I. -0.02 to $0.94, p=0.07)$ in log proinsulin. These trends were independent of gestational age.

Systolic blood pressure increased with body mass index. An increase in body mass index of $1 \mathrm{~kg} / \mathrm{m}^{2}$ was associated with an increase of $2.6 \mathrm{~mm} \mathrm{Hg}(95 \%$ C.I. 1.2 to $4.1, p=0.001$ ). After allowing for body mass index systolic blood pressure increased with plasma glucose. An increase of $1 \mathrm{mmol} / 1$ in 30-min plasma glucose was associated with a $2.9 \mathrm{~mm} \mathrm{Hg}$ increase in systolic blood pressure $(95 \%$ C. I. 0.4 to $5.4, p=0.03)$. No trend was seen between systolic blood pressure and birthweight, placental weight, head circumference, plasma insulin or proinsulin.

Mean plasma glucose levels according to subject's social class at birth were $8.0 \mathrm{mmol} / \mathrm{l}$ in classes I, II, III nonmanual $(n=8), 8.0 \mathrm{mmol} / \mathrm{l}$ in social class III manual $(n=$ $22)$ and $8.4 \mathrm{mmol} / \mathrm{l}$ in classes IV and V $(n=7)$. The corresponding mean birthweights were 3558 (SD 423)g, 3353 (SD 376) g and 3450 (SD 301) g.

\section{Discussion}

We have shown that among 21-year-old men, 30-min plasma glucose levels are higher in those who had lower birthweight, while, after allowance for glucose, 30 -min plasma insulin and proinsulin levels are lower. Our sample was selected from male subjects born in the Maternity Unit in Southampton. Though the sample is unlikely to be representative of all young men in Southampton their mean birthweight, $3.4 \mathrm{~kg}$, is close to the national average. Our analysis was based on internal comparisons, and bias would be introduced only if the relationship between fetal growth and plasma glucose in the sample was unusual which seems unlikely.

Our findings are consistent with those in a study of men aged 64 years in whom 30 -min and 2-h plasma glucose, and the risk of impaired glucose tolerance and diabetes fell progressively with increasing birthweight, and independently of waist-hip ratio and body mass index [4]. The strength of the association in 21-year-old men is such that 30 -min plasma glucose decreased by $0.70 \mathrm{mmol} / 1$ per pound of birthweight. The corresponding figure for 64 -year-old men was $0.22 \mathrm{mmol} / \mathrm{l}$, which just exceeds the lower confidence limit for the figure for 21-year-old men.

The association between 30-min plasma glucose and birthweight in the present study was independent of social class at birth and adult height. This suggests that the asso- 
ciation is not the result of confounding environmental influences which are associated both with retarded fetal growth and with the later development of impaired glucose tolerance.

Blood pressure was related to $30-\mathrm{min}$ plasma glucose in keeping with previous observations on children and adults $[8,9]$. The association was independent of body mass index. The unexpectedly high mean systolic pressure of $146 \mathrm{~mm} \mathrm{Hg}$ may be a consequence of recording blood pressure on the same occasion as glucose tolerance testing. Unlike plasma glucose blood pressure was not associated with lower birthweight, though this association has been found in larger studies [10].

The trends of 30-min plasma glucose, insulin and proinsulin with birthweight were independent of gestational age. They may therefore reflect retarded fetal growth. The relation between retarded fetal growth and higher 30-min plasma glucose but lower 30-min plasma insulin and proinsulin (allowing for plasma glucose level and body mass index) suggests deficient insulin production by men who had lower birthweight. Our findings are consistent with the hypothesis that impaired glucose tolerance and diabetes in adult life may result from nutritional and other influences which retard growth of the pancreas, and reduce the number and/or size of the pancreatic Beta-cell complement [4].

Acknowledgements. We are grateful to the men who took part in the study and to the staff at Shirley Health Centre for their co-operation, to Ms. M. Dudleston for help with the fieldwork and Mr. P. Winter for computing the data.

\section{References}

1. Barker DJP, Winter PD, Osmond C, Margetts B, Simmonds SJ (1989) Weight in infancy and death from ischaemic heart disease. Lancet II: $577-580$
2. Barker DJP (1991) The intrauterine origins of cardiovascular and obstructive lung disease in adult life. J Roy Coll Phys 25: 129-133

3. The Childhood Environment and Adult Disease (1991) Ciba Foundation Symposium 156. Wiley \& Sons, Chichester

4. Hales CN, Barker DJP, Clark PMS et al. (1991) Fetal and infant growth and impaired glucose tolerance at age 64 years. Br Med J 303: 1019-1022

5. Sobey WJ, Beer SF, Carrington CA et al. (1989) Sensitive and specific two site immunoradiometric assays for human insulin, proinsulin, 65-66 split and 32-33 split proinsulins. Biochem $\mathrm{J}$ 260:535-541

6. Office of Population Censuses \& Surveys (1980) Classification of Occupations 1980. HMSO, London

7. National Diabetes Data Group (1979) Classification and diagnosis of diabetes mellitus and other categories of glucose intolerance. diabetes 28: 1039-1057

8. Florey C du V, Uppal S, Lowy C (1976) Relation between blood pressure, weight, and plasma sugar and serum insulin levels in school children aged 9-12 years in Westland Holland. Br Med J 1: 1368-1371

9. Cambien F, Warnet JM, Eschwege E, Jacqueson A, Richard JL, Rosselin G (1987) Body mass, blood pressure, glucose and lipids. Does plasma insulin explain their relationships? Arteriosclerosis 7:197-202

10. Barker DJP, Bull AR, Osmond C, Simmonds SJ (1990) Fetal and placental size and risk of hypertension in adult life. Br Med J 301: $259-262$

Received: 14 October 1991

and in revised form: 20 December 1991

Dr. S. Robinson

Medical Research Council Environmental Epidemiology Unit Southampton General Hospital

Southampton $\mathrm{S} 09$ 4XY

UK 